City University of New York (CUNY)

CUNY Academic Works

\title{
Stereospecific Opiate Binding in Human Erythrocyte Membranes and Changes in Heroin Addicts
}

Leo G. Abood

University of Rochester School of Medicine and Dentistry

Holly G. Atkinson

CUNY City College

Mary MacNeil

University of Rochester School of Medicine and Dentistry

\section{How does access to this work benefit you? Let us know!}

More information about this work at: https://academicworks.cuny.edu/cc_pubs/391

Discover additional works at: https://academicworks.cuny.edu

This work is made publicly available by the City University of New York (CUNY).

Contact: AcademicWorks@cuny.edu 


\title{
STEREOSPECIFIC OPIATE BINDING IN HUMAN ERYTHROCYTE MEMBRANES AND CHANGES IN HEROIN ADDICTS
}

\author{
Leo G. Abood, Holly G. Atkinson, and Mary MacNeil \\ Center for Brain Research and Department of Biochemistry, University of \\ Rochester Medical Center, Rochester, New York
}

\begin{abstract}
Stereospecific opiate binding has been demonstrated in human erythrocyte membranes, having a $\mathrm{K}_{\mathrm{d}}$ of $9 \cdot 10^{-9} \mathrm{M}$. In most respects the binding characteristics resemble those of snyaptic membranes. These included the correlation of binding affinity and pharmacological potency of opiates; competition by naloxone; inhibition by $\mathrm{Ca}^{2+}$ and $\mathrm{Na}^{+}$; and sensitivity to phospholipases and trypsin. A comparison of stereospecific opiate binding in control human subjects and heroin addicts revealed a $43 \%$ increase in the addict group.
\end{abstract}

Key words: opiate binding, heroin addicts, ery throcytes, membranes

In recent years, there has been considerable interest in the identification of the "opiate receptor" in brain tissue, and in the attempt to correlate the binding affinity of opiates to their pharmacological action (Goldstein et al., 1971; Pert and Snyder, 1973; Simon et al., 1973). Our interest in opiate binding developed from the observation that phosphatidyl serine not only exhibited stereospecific binding for opiates (Abood and Hoss, 1975), but its addition to neural membrane preparations significantly enhanced stereospecific binding (Abood and Takeda, 1976). Since erythrocyte membranes contain a significant amount of phosphatidyl serine (Pasternak and Snyder, 1974), while the total lipid extract exhibits opiate binding, a study was undertaken to determine whether high affinity opiate binding occurred in the membranes. Initial attempts to demonstrate stereospecific opiate binding to intact erythrocytes were unsuccessful, largely due to the fact that the hemoglobin, which leaked out into the incubation medium, was inhibitory to binding. The present study established that human erythrocyte membranes exhibit high affinity stereospecific binding for opiates, and that the binding site has many characteristics of the sites present in the brain tissue. In addition, a comparison was made of opiate binding in erythrocyte membranes of control subjects and heroin addicts.

Address reprint requests to Leo G. Abood, Ph.D., Center for Brain Research, Box 605, University of Rochester Medical Center, Rochester, NY 14642. 
Freshly drawn heparinized human blood was diluted with 5 volumes of $10 \mathrm{mM}$ icecold Tris-EDTA, pH 7.5, and after $30 \mathrm{~min}$ was centrifuged at $100,000 \mathrm{~g}$ for $30 \mathrm{~min}$. The pellet was homogenized in five times the original blood volume of $10 \mathrm{mM}$ Tris-EDTA and recentrifuged. The washing procedure was repeated four times or until the hemoglobin had been removed. Stereospecific opiate binding was measured by the technique of Pert and Snyder (1973). A typical incubation medium contained the following in a final volume of $1.2 \mathrm{ml}: 0.05 \mathrm{M}$ Tris, $\mathrm{pH} 7.5,0.05 \mu \mathrm{C}$ of ${ }^{3} \mathrm{H}$-dihydromorphine $\left({ }^{3} \mathrm{H}-\mathrm{DHM}\right)$, specific activity 71 curies/mmole, and either $10^{-7} \mathrm{M}$ levorphanol or dextrorphan. After 15 -min incubation at $35^{\circ} \mathrm{C}$, the samples were filtered by suction through a Whatman GF/B glass fiber filter, which was washed twice with $5 \mathrm{ml}$ of ice-cold Tris buffer and transferred to a liquid scintillation vial for measuring radioactivity. All of the addicts used in the study were presently on heroin and had been on the drug for at least 1 year. The group consisted of seven males and three females ranging in age from 21 to 35 years.

In an effort to compare the opiate binding characteristics of erythrocyte membranes to those of brain tissue, the effect of a number of parameters known to influence the latter were examined (Table I). All values were expressed in terms of specific binding, which represented the difference in counts/min of the bound ${ }^{3} \mathrm{H}-\mathrm{DHM}$ in the presence of $10^{-7} \mathrm{M}$ dextrorphan from that in the presence of the experimental agent. At a concentration of $10^{-7} \mathrm{M}$ hydromorphone produced complete inhibition and morphine $85 \%$,

TABLE I. Effect of Various Treatments on Binding of ${ }^{3} \mathrm{H}-\mathrm{DHM}$ to Erythrocyte Membranes

\begin{tabular}{lcccc}
\hline & $\begin{array}{c}\text { 3 H-DHM } \\
\text { bound }\end{array}$ & $\begin{array}{c}\text { Specific } \\
\text { binding, } \\
\text { cpm }\end{array}$ & \% change & \% brain change \\
\hline Dextorphan & 845 & - & - & - \\
Levorphanol & 602 & 243 & - & - \\
Hydromorphone & 586 & 259 & -106 & -100 \\
Morphine & 638 & 207 & -85 & -90 \\
Codeine & 786 & 59 & -25 & -45 \\
Naloxone & 713 & 45 & -18 & -95 \\
10 & 590 & 255 & -104 & -95 \\
0.05 M NaC1 & 580 & 265 & -109 & -100 \\
Philpase A & 610 & 235 & -97 & -90 \\
Philpase C & 603 & 242 & -100 & -50 \\
Trypsin & 552 & 293 & -120 & -100 \\
P-Serine & 705 & 140 & -58 & +35 \\
\hline
\end{tabular}

Membranes were exposed to various treatments or drugs 30 min prior to the addition of ${ }^{3} \mathrm{H}$-DHM. Incubation medium described in text; each tube containing $1.3 \mathrm{mg}$ membrane protein. Amounts of phospholipase A (bee venom), phospholipase C (B. cereus) and trypsin (crystalline, treated with diphenyl carbamyl choline) was 1 unit, 2 units, and $0.2 \mathrm{mg}$ respectively. Phosphatidyl serine was $99 \%$ pure (bovine brain) and used at a concentration of $100 \mu / \mathrm{mg}$ protein. See (5) for details on use of enzymes and phosphatidyl serine.

*Specific binding: $\frac{(243-\text { column } 2) \cdot 100}{243}$.

The values represent the mean of three separate experiments run in triplicate, and the variation from the mean was less than $6 \%$. 
values comparable to those obtained with rat brain synaptic membranes. Codeine, a weaker opiate, produced a $35 \%$ inhibition in erythrocytes as compared with $45 \%$ in the brain. On the other hand, the opiate antagonist naloxone had only a small effect on erythrocytes at a concentration completely inhibitory to brain. Both $\mathrm{CaCl}_{2}\left(10^{-3} \mathrm{M}\right)$ and $\mathrm{NaC1}(0.05 \mathrm{M})$ produced complete inhibition in both preparations, as did exposure to phospholipase $\mathrm{A}$ and trypsin. The erythrocyte appeared to be more sensitive to treatment with phospholipase C. Upon the addition of phosphatidyl serine $(100 \mu \mathrm{g} / \mathrm{mg}$ membrane protein $)$, binding was inhibited $58 \%$ as compared to a $35 \%$ enhancement of synaptic membranes.

A Scatchard analysis was performed on the stereospecific opiate binding of erythrocyte membranes from control human blood (Fig. 1). The $\mathrm{K}_{\mathrm{d}}$ was calculated to be 9 $10^{-9} \mathrm{M}$. This value compares with the lower affinity binding of brain tissue which exhibits a biphasic Scatchard plot with $\mathrm{K}_{\mathrm{d}} \mathrm{s}$ of $5 \cdot 10^{-10} \mathrm{M}$ and $8 \cdot 10^{-9} \mathrm{M}$ (Abood and Takeda, 1976; Pasternak and Snyder, 1975).

A preliminary study was performed on the stereospecific binding of erythrocy tes obtained from a group of ten heroin addicts and an equal number of control subjects (Table II). The mean value of the control group was $130 \pm 25$, with the range being 115-180. This compares with a mean of $202 \pm 38$ in the addicts, with a range of $160-225$. The mean is $43 \%$ greater in the addict than in the control group, the difference being significant at $\mathbf{P}<0.01$ ( $t$ test). It should be emphasized that the population of both control subjects and heroin addicts is too small to conclude that opiate binding increases during drug addiction; however, the data do encourage a more extensive study.

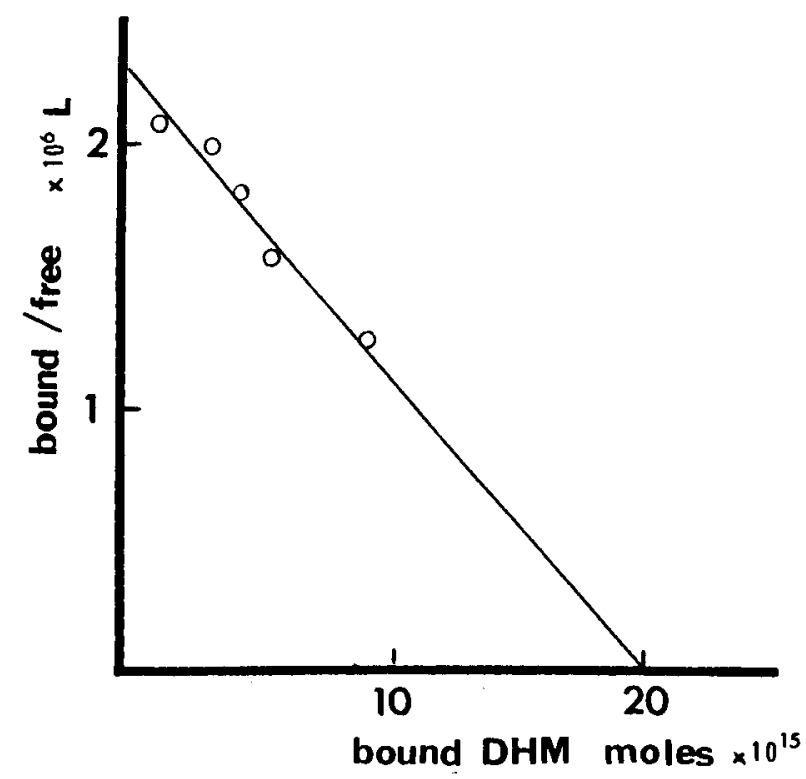

Fig. 1. Scatchard plot of ${ }^{3} \mathrm{H}$-dihydromorphine binding to human erythrocyte membranes. All assays were run in triplicate and represent two separate experiments. Binding is stereospecific, representing the difference in the presence of $10^{-7} \mathrm{M}$ levorphanol and dextorphan. Each tube contained $1 \mathrm{mg}$ membrane protein in $0.05 \mathrm{M}$ Tris, $\mathrm{pH} 7.5$, and varying concentrations of ${ }^{3} \mathrm{H}$-dihydromorphine. The points are an average of three separate experiments run in triplicate; the variation from the mean being no more than $6 \%$. 
TABLE II. Stereospecific Opiate Binding in Erythrocyte Membranes of Control Human Subjects and Heroin Addicts

\begin{tabular}{lcccc}
\hline & $\begin{array}{c}\text { No. of } \\
\text { subjects }\end{array}$ & $\begin{array}{c}{ }^{3} \mathrm{H}-\mathrm{DHM} \\
\text { binding }\end{array}$ & Range & $\begin{array}{c}\% \\
\text { Increase }\end{array}$ \\
\hline Controls & 10 & $\begin{array}{c}\text { cpm } \\
130 \pm 25\end{array}$ & $115-180$ & - \\
Addicts & 10 & $202 \pm 38$ & $160-225$ & $43^{*}$ \\
\hline
\end{tabular}

Stereospecific binding was expressed as difference in $\mathrm{cpm}$ of bound ${ }^{3} \mathrm{H}-\mathrm{DHM}$ in the presence of $10^{-6} \mathrm{M}$ dextrorphan from that in the presence of $10^{-7} \mathrm{M}$ levorphanol. Values are expressed as mean \pm standard deviation counts $/ \mathrm{min} / \mathrm{mg}$ protein

*Significant at $\mathrm{P}<0.01(\mathrm{t}$ test).

The significance of the present study in terms of the pharmacological action of opiates is difficult to assess. It is, however, apparent that the characteristics of the opiate binding in erythrocyte membranes are very similar to those of brain tissue. Opiate binding in both tissues is inhibited by phospholipase $\mathrm{A}$ or $\mathrm{C}$ as well as by trypsin and $\mathrm{NaC}$. The opiate antagonist naloxone is antagonistic to ${ }^{3} \mathrm{H}$-DHM binding in both preparations; however, the erythrocyte is only one-fifth as sensitive as synaptic membranes. Both $\mathrm{Ca}^{2+}$ and $\mathrm{Na}^{+}$are completely inhibitory to both types of membranes. There appears to be a relationship between the affinity of various opiates and their pharmacological potency, hydromorphone being the most potent opiate and codeine the least. A major difference was the effect of added phosphatidyl serine which significantly enhanced opiate binding in brain tissue but was actually inhibitory to that in erythrocytes. Erythrocy tes already contain a comparatively large proportion of phosphatidyl serine, as much as $20 \%$ of the total phospholipid (Rouser et al., 1968); consequently, all binding sites evidently have their complement of this lipid. As discussed elsewhere (Abood and Takeda, 1976; Abood et al., in press), stereospecific opiate binding in neural membranes is significantly enhanced by phosphatidyl serine, a finding which suggests that phosphatidyl serine may be a component of the binding site.

Although the observed increase in opiate binding in the erythrocyte membranes of heroin addicts is based on only a few subjects, chronic drug usage is generally associated with a variety of adaptive mechanisms. The observation is also in conformity with the report that chronic administration of opiates to rats increases the number of opiate binding sites in the brain (Pert and Snyder, 1976).

A major difference was the inability of naloxone to compete for the erythrocyte binding site. At present the only plausible explanation for this difference is that the presence of the N-allyl substituent on the opiate molecule tends to interfere with binding to the erythrocyte membrane. This conclusion is supported by the finding that $\mathrm{N}$-allylmorphine and levalorphan, which are also morphine antagonists, at concentrations of $10^{-7} \mathrm{M}$ do not interfere with ${ }^{3} \mathrm{H}$-DHM binding. It would appear that the reversal of opiate binding by antagonists, which is so characteristic of the brain receptor, is absent from erythrocytes. 


\section{ACKNOWLEDGMENTS}

This research was supported by USPH grant 00464 and a grant from the Council for Tobacco Research. Blood was provided by Dr. Joseph Maxey and the Methadone Clinic of the University of Rochester.

\section{REFERENCES}

Abood, L. G., and Hoss, W. (1975). Stereospecific morphine adsorption to phosphatidyl serine and other membranous components of brain. Eur. J. Pharmacol. 32:66-75.

Abood, L. G., and Takeda, F. (1976). Enhancement of stereospecific opiate binding to neural membranes by phosphatidyl serine. Eur. J. Pharmacol. 39:71-77.

Abood, L. G., Takeda, F., and Salem, N. (in press). In: "Neurochemical and Behavioral Mechanisms of Alcohol and Opiate Dependence" (K. Blum, ed.). New York: Academic Press.

Goldstein, A., Lowney, L. I., and Pal, B. K. (1971). Stereospecific and nonspecific interactions of the morphine congener levorphanol in subcellular fractions of mouse brain. Proc. Nat. Acad. Sci. USA 68:1742-1747.

Pasternak, G. W., and Snyder, S. H. (1974). Opiate receptor binding: Effects of enzymatic treatments. Mol. Pharmacol. 10:183-193.

Pasternak, G. W., and Snyder, S. H. (1975). Identification of novel high affinity opiate receptor binding in rat brain. Nature 253:563-565.

Pert, C. B., and Snyder, S. H. (1973). Properties of opiate receptor binding in rat brain. Proc. Nat. Acad. Sci. USA 70:2243-2247.

Pert, C. B., and Snyder, S. H. (1976). Opiate receptor binding - enhancement by opiate administration in vivo. Biochem. Pharmacol. 25:847-853.

Rouser, G., Nelson, G. J., Fleischer, S., and Simon, G. (1968). In "Biological Membranes Physical Fact and Function" (D. Chapman, ed.). New York: Academic Press, p. 5.

Seeman, P. (1972). The membrane actions of anesthetics and tranquilizers. Pharmacological Rev. 24: 583.

Sheetz, M. P., and Singer, S. J. (1974). Biological membranes as bilayer couples. A molecular mechanism of drug-erythrocyte interactions. Proc. Nat. Acad. Sci. USA 71:4457.

Simon, E. J., Hiller, J. M., and Edelman, I. (1973). Stereospecific binding of the potent narcotic analgesic ${ }^{3}$ H-ethorphine to rat brain homogenate. Proc. Nat. Acad. Sci. USA 70:1947-1949.

Skou, J. C. (1958). Relationship between the ability of various compounds to block nervous conduction and their penetration into a monomolecular layer of nerve-tissue lipids. Biochim. Biophys. Acta 30:625. 